\title{
STABILITAS HASIL DAN ADAPTABILITAS KULTIVAR TEMBAKAU LOKAL MAGETAN MENGGUNAKAN METODE EBERHART RUSSELL
}

\section{YIELD STABILITY AND ADAPTATION OF MAGETAN LOCAL TOBACCO CULTIVARS USING EBERHART RUSSELL METHODS}

\author{
Ruly Hamida*, Mala Murianingrum dan Djumali \\ Balai Penelitian Tanaman Pemanis dan Serat \\ J1. Raya Karangploso, P.O. Box 199, Malang \\ *Email:h_mee_da@yahoo.com
}

\begin{abstract}
Magetan local tobacco is one type of tobacco that has an important role in the kretek cigarette industry in Indonesia. Some tobacco varieties have been widely cultivated in the Magetan Regency, but the level of plant heterogeneity is quite high. The purpose of this study was to assess the yield, stability and adaptability of local varieties that developed in Magetan Regency. The research material consists of 7 tobacco varieties, namely Rejeb 1, Rejeb 2, Rejeb 3, Rejeb 4, Rejeb 5, Rejeb 6, and Rejeb 7. Each variety was planted in a $12 \mathrm{~m} \times 4.50 \mathrm{~m}$ plot with a spacing of $60 \mathrm{~cm} \times 90 \mathrm{~cm}$ (100 plants / plot). This study used a randomized block design with three replications. The stability of the results was analyzed by the Eberhart and Russell methods. The results showed that Rejeb 4 cultivar gave the highest and stable yield of 598.89 $\mathrm{kg} / \mathrm{ha}$, higher than all cultivars tested. This is in line with the quality index and plant index values, where the Rejeb 4 variety gave the highest value in five test locations (63.65 and 38.34). Subsequently followed by cultivars Rejeb 3, Rejeb 2, and Rejeb 1 which have dynamic stability and adaptability values.
\end{abstract}

Keywords: Adaptability, yield, stability, tobacco

\begin{abstract}
ABSTRAK
Tembakau lokal Magetan merupakan salah satu jenis tembakau yang memiliki peran penting dalam industri rokok kretek di Indonesia. Beberapa varietas tembakau telah banyak dibudidayakan di wilayah Kabupaten Magetan, tetapi tingkat heterogenitas tanaman cukup tinggi. Tujuan penelitian ini untuk menilai daya hasil, stabilitas, dan adaptabilitas kultivarlokal yang berkembang di Kabupaten Magetan. Perlakuan terdiri atas 7varietas tembakau, yaitu Rejeb 1, Rejeb 2, Rejeb 3, Rejeb 4, Rejeb 5, Rejeb 6, dan Rejeb 7. Rancangan percobaan menggunakan Rancangan Acak Kelompok dengan tiga ulangan. Tiap-tiap kultivar dalam satu ulangan ditanam pada petak seluas $12 \mathrm{~m}$ x 4,50 m dengan jarak tanam $60 \mathrm{~cm}$ x $90 \mathrm{~cm}$ (100 tanaman/petak). Stabilitas hasil dianalisis dengan metode Eberhart dan Russell.Hasil penelitian menunjukkan bahwa Kultivar Rejeb 4 memberikan hasil rajangan kering tertinggi dan stabil yaitu 598,89 kg/ha, lebih tinggi dibandingkan dengan semua kultivar yang diuji. Hal ini selaras dengan nilai indek mutu dan indek tanaman, dimana varietas Rejeb 4 memberikan hasil tertinggi di lima
\end{abstract}


lokasi pengujian (63,65 dan 38,34). Selanjutnya disusul oleh kultivar Rejeb 3, Rejeb 2, dan Rejeb 1 yang memiliki nilai stabilitas dan adaptabilitas dinamis.

Kata Kunci : Adaptabilitas, daya hasil,stabilitas, tembakau, varietas

\section{PENDAHULUAN}

Tembakau lokal memiliki peran penting dalam industri rokok kretek di Indonesia, karena 80\% racikan rokok kretek menggunakan tembakau lokal.Tembakau lokal memiliki banyak tipe, setiap tipe memiliki daya adatasi yang relatif sempit dan hanya berkembang di suatu wilayah yang terbatas. Pada umumnya setiap tipe dinamakan sesuai dengan wilayah pengembangannya.

Salah satu wilayah di Jawa Timuryang memiliki potensi pengembangan tembakau lokal adalah Kabupaten Magetan. Hasil observasi tim Balittas dan informasi dari Dinas Tanaman Pangan, Hortikultura, Perkebunan, dan Ketahanan Pangan Kabupaten Magetan diketahui bahwa saat ini daerah pengembangan utama tembakau lokal terletak pada9 Desa di Kecamatan Parang, yaitu Desa Trosono, Sayutan, Parang, Krajan, Sundul, Tamanarum, Pragak, Ngunut, dan Nglopang (Dinas TPHPKP Kabupaten Magetan, 2016). Varietas lokal tembakau di Kabupaten Magetan yang banyak berkembang adalah varietas Rejeb dengan berbagai perbedaan karakter morfologimaupun hasil.

Sesuai dengan Permentan RI No.50/ Permentan/ KB.020/9/2015 varietas-varietas lokal tersebut perlu ditingkatkan menjadi varietas unggul lokal. Disamping itu,Undang-undang 12 Tahun 1992, PP 44 Tahun 1995 dan Permentan 39 Tahun 2006 mengamanatkan bahwa benih yang beredar di masyarakat harus bersertifikat dan berlabel. Sedangkan benih yang dapat disertifikasi hanya benih bina, yaitu benih dari varietas yang sudah dilepas oleh Menteri Pertanian. Salah satu upaya ng dilakukan yaitu dengan pemurnian dan pemutihan varietas lokal. Keunggulan varietas lokal salah satunya telah beradaptasi baik pada lingkungan spesifik, serta telah diadopsi dan disukai petani. Pengujian multilokasigenotipe merupakan hal yang umum dilakukan dalam proses pemuliaan (pemurnian dan pemutihan), dengan tujuan mempelajari potensi hasil genotipe harapan dan menganalisis stabilitas hasil berdasarkan interaksi genetik dan lingkungan (Satoto et al. 2007). Tingkat stabilitas suatu genotipe penting diketahui guna menduga respon genotipe tersebut terhadap lingkungan dan mengantisipasi lingkungan yang kurang sesuai untuk budidayanya (Satoto et al. 2010). Suatu tanaman budidaya, termasuk tembakau tidak hanya ditentukan oleh kemampuan untuk berproduksi maksimal pada lingkungan yang sesuai, tetapi juga memiliki kelayakan adaptasi pada lingkungan yang luas. Salah satu teknik yang sering digunakan melalui analisa regresi (Finlay dan Wilkinson, 1963; Eberhart dan Russel, 1966)

Penelitian ini bertujuan untuk mengetahui daya hasil, stabilitas hasil dan adaptabilitas tujuh kultivar tembakau lokal Kabupeten Magetan yang telah dimurnikan, sebagai bahan pertimbangan pelepasan varietas unggul lokal. 


\section{BAHAN DAN METODE}

Penelitian telah dilakukan di lima lokasi di Kabupaten Magetan yang merepresentasikan sentra penanaman tembakau pada musim tanam 2013-2016. Lokasi penelitian tersaji pada Tabel 1. Bahan yang digunakan meliputi adalah benih 7 kultivar tembakau lokal Magetan, pupuk organik, pupuk anorganik dan bahan pembantu lainnya.

Perlakuan terdiri atas 7 kultivar Rejeb (Rejeb 1, Rejeb 2, Rejeb 3, Rejeb 4, Rejeb 5, Rejeb 6, dan Rejeb 7). Perlakuan disusun dalam rancangan acak kelompok dengan 3 ulangan. Setiap petak perlakuan dalam satu ulangan terdiri dari 100 tanaman. Benih ditanam pada umur 45 hari setelah sebar dengan jarak tanam 60 x $90 \mathrm{~cm}$. Pemupukan menggunakan $15 \mathrm{~g}$ ZA, $15 \mathrm{~g} \mathrm{SP}_{36}$ dan $15 \mathrm{~g}$ ZK per tanaman. Pengairan dilakukan dengan sistem penggenangan menggunakan pompa air. Pengendalian hama dan penyakit sesuai kebutuhan atau tingkat keparahan di lapangan.Parameter pengamatan antara lainhasil rajangan kering dilakukan dengan mengambil sampel $10 \%$ dari total populasi. Indeks mutu dihitung dengan persamaan (GAPPARI, 1950 dalam Rachman et al. 1993) sebagai berikut :

$$
\operatorname{Im}=\frac{\sum(\text { ai } \times \text { bi })}{\sum_{\substack{n \\ \mathrm{i}=1}}^{\mathrm{n}}}
$$

Keterangan: $\quad \operatorname{Im}=$ Indeks mutu

ai = indeks harga perlakuan ke i

bi $=$ berat mutu perlakuan ke $\mathrm{i}$

$\mathrm{n}$ = Banyaknya mutu
Indeks Tanaman dihitung menggunakan rumus : indeks mutu $\mathrm{x}$ hasil rajangan kering (ton/ha).Analisis nikotin dengan metode ekstraksi etherpetroleum ether, dan selanjutnya dititrasi dengan $\mathrm{HCl}$ (Badan Litbang Industri, 1983).

Data hasil pengamatan dianalisis dengan sidik ragam gabungan menggunakan perangkat lunak MSTAT versi 4.00/EM. Pendugaan interaksi genetik dengan lingkungan dilakukan dengan analisis ragam gabungan semua lokasi dimana genetik direpresentasikan oleh kultivar dan lingkungan oleh lokasi. Apabila terjadi interaksi antar varietas dengan lingkungan, maka untuk mengetahui stabilitas masingmasing varietas dilakukan analisis lanjutan menggunakan metode Eberhart \& Russell (1966) dengan model persamaan :

$$
Y_{\mathbf{i j}}=\boldsymbol{\mu} \mathbf{i}+\boldsymbol{\beta} \mathbf{i} \mathbf{I j}+\boldsymbol{\delta} \mathbf{i j}
$$

dimana:

$Y_{i j}=$ rata-rata hasil galur ke-i pada lingkungan ke-j $\mu i=$ rata-rata hasil galur ke-i pada semua lingkungan

$\beta i=$ koefisien regresi dari rata-rata hasil galur ke-i(y) terhadap indeks lingkungan(x)

$I j=$ indeks lingkungan, yaitu simpangan rata- rata semua galur pada suatu lingkungan dari rata-rata umum, $\mathrm{Ij}=(\Sigma \mathrm{j} Y \mathrm{ij} / \mathrm{v})-\left(\sum \mathrm{i} \Sigma \mathrm{j} Y \mathrm{ij} / \mathrm{vn}\right)$

$\delta \mathrm{ij}=$ simpangan dari regresi hasil galur ke-i di lingkungan ke-j

Parameter stabilitas terdiri atas:

a. Koefisien regresi (bi) diduga:

$$
b_{i}=\Sigma j Y i j I j / \Sigma j I^{2} j
$$

b. Simpangan regresi $\left(\delta^{2} \mathrm{~d}_{\mathrm{ij}}\right)$ diduga:

$$
S^{2} d i=\Sigma j \hat{S}^{2} i j(n-2)-S^{2} e / r
$$


Tabel 1. Spesifikasi agroekologi masing-masing lokasi pengujian

\begin{tabular}{clclc}
\hline Tahun & Lokasi (Desa - Kec.) & Tipe lahan & \multicolumn{1}{c}{ Jenis Tanah } & Ketinggian \\
\hline \multirow{2}{*}{2013} & Tamanarum - Krajan & Sawah & Lempung berpasir & $293 \mathrm{~m} \mathrm{dpl}$ \\
\multirow{2}{*}{2014} & Ngunut - Parang & Sawah & Lempung berpasir & $327 \mathrm{~m} \mathrm{dpl}$ \\
& Ngunut - Parang & Tegal & Lempung berliat & $397 \mathrm{~m} \mathrm{dpl}$ \\
\multirow{2}{*}{2016} & Ngunut - Parang & Sawah & Lempung berpasir & $327 \mathrm{~m} \mathrm{dpl}$ \\
& Pendem - Ngariboyo & Tegal & Lempung berliat & $304 \mathrm{dpl}$ \\
\hline
\end{tabular}

Tabel 2. Sidik ragam analisis gabungan terhadap karakter rajangan kering, indeks mutu, indeks tanaman dan kadar nikotin

\begin{tabular}{lllll}
\hline \multirow{2}{*}{ Sumber variasi } & \multicolumn{4}{c}{ Kuadrat Tengah } \\
\cline { 2 - 5 } & \multicolumn{1}{c}{ Rajangan kering } & \multicolumn{1}{c}{ Indeks Mutu } & \multicolumn{1}{c}{ Indeks Tanaman } & Kadar Nikotin \\
\hline Lokasi & $\left.233295,82^{* *}\right)$ & $\left.1368,81^{* *}\right)$ & $\left.3435,67^{* *}\right)$ & $\left.23,80^{* *}\right)$ \\
Kultivar & $\left.30502,46^{* *}\right)$ & $\left.96,64^{*}\right)$ & $\left.160,68^{* *}\right)$ & $\left.0,53^{*}\right)$ \\
Kultivar x Lokasi & $\left.16872,85^{* *}\right)$ & $40,17^{\text {tn }}$ & $\left.74,98^{* *}\right)$ & $0,33^{\text {tn }}$ \\
Galat & 2675,73 & 51,94 & 17,52 & 0,39 \\
\hline
\end{tabular}

Keterangan : ${ }^{* *}$ sangat nyata pada taraf $1 \%,{ }^{*}$ nyata pada taraf $5 \%$, tn) tidak berbeda nyata

dimana:

$\mathrm{S}^{2} \mathrm{e} / \mathrm{r}=\mathrm{n}$ dugaan galat gabungan (ragam dari rata-rata

suatu galur pada lingkungan ke-j

$\Sigma j S^{2} i j=\left(\Sigma j Y^{2} i j-Y^{2} j / n\right)-(\Sigma i j Y i j I j)^{2} / \Sigma j I^{2} j$

Suatu galur/varietas dianggapmantap atau stabil apabila galur/varietas tersebut memiliki nilai koefisien regresi tidak berbeda dengan nilai reratanya $(\mathrm{bi})=1,0$ dan nilai simpangan regresinya tidak berbeda nyata dengan nol $\left(\mathrm{S}^{2} \mathrm{di}=0\right)$.

\section{HASIL DAN PEMBAHASAN}

\section{Daya hasil tembakau}

Daya hasil tembakau mencakup hasil rajangan kering, indeks mutu, indek tanaman dan kadar nikotin. Hasil analisis ragam gabungan menunjukkan bahwa interaksi antara lokasi dan kultivar hanya berpengaruh terhadap komponen rajangan kering dan indeks tanaman saja, sedangkan lokasi dan kultivar secara individu berpengaruh terhadap semua komponen daya hasil tembakau (Tabel2). Pengaruh kultivar terhadap semua komponen daya hasil tersebut menunjukkan bahwa kultivar yang diuji cukup bervariasi dan ini memberikan peluang untuk terjadinya pemilihan kultivar unggul secara efektif. Demikian pula pengaruh lokasi terhadap semua komponen daya hasil tersebut menunjukkan bahwa lingkungan yang digunakan untuk uji multilokasi sangat bervariasi.

Hasil rajangan kering merupakan faktor utama bagi petani tembakau untuk menentukan pilihan terhadap varietas yang akan dibudidayakan, karena hasil panen berbanding lurus dengan penerimaan petani. Kultivar Rejeb 4 memberikan hasil rajangan kering tertinggi padatiga lokasi, yakni Tamanarum, Ngunut Tegal dan Pendem, sedangkan Rejeb 6 hanya memberikan hasil tertinggi pada lokasi Ngunut Sawah 
2014 (Tabel 3). Adapun kultivar Rejeb 2 hanya memberikan hasil tertinggi pada lokasi Ngunut Sawah 2016, demikian pula kultivar Rejeb 5 hanya memberikan hasil tertinggi pada lokasi Ngunut Tegal.Kultivar Rejeb 1 dan Rejeb 7 masing-masing menghasilkan rajangan kering terendah pada dua lokasi, yakni pada Ngunut Sawah 2014 dan 2016 untuk kultivar Rejeb 1 serta Tamanarum dan Ngunut Tegal untuk kultivar Rejeb 7.

Mutu merupakan faktor penting bagi tembakau sebagai bahan penikmat. Mutu tembakau merupakan resultante dari rasa, aroma, warna, pegangan dan lain- lain. Mutu tembakau (grade) juga dipengaruhi oleh selera konsumen (pabrik rokok). Mutu yang diinginkan oleh pabrik rokok tertentu bisa berbeda dengan mutu yang diinginkan oleh pabrik rokok lain. Pada umumnya pabrik rokok lebih memilih tembakau dari segi aroma dan rasanya yang ringan, karena digunakan sebagai bahan racikan. Sedangkan konsumen rokok tradisional (lintingan) lebih memilih pada rasa isapan yang lebih berat (ampeg).

Indeks mutu tembakau Rejeb merupakan peubah yang mencerminkan dari harga tembakau tersebut. Semakin tinggi harga yang diperoleh semakin

Tabel 3. Hasil rajangan kering 7 kultivar Rejeb pada 5 lokasi pengembangan tembakau di Kabupaten Magetan.

\begin{tabular}{lccccc}
\hline \multirow{2}{*}{ Kultivar } & \multicolumn{5}{c}{ Hasil rajangan kering (kg/ha) pada lokasi } \\
\cline { 2 - 6 } & $\begin{array}{c}\text { Tamanarum } \\
\text { (sawah,2013) }\end{array}$ & $\begin{array}{c}\text { Ngunut } \\
\text { (sawah,2014) }\end{array}$ & Ngunut (tegal,2014) & $\begin{array}{c}\text { Ngunut } \\
\text { (sawah 2016) }\end{array}$ & $\begin{array}{c}\text { Pendem } \\
\text { (tegal 2016) }\end{array}$ \\
\hline Rejeb 1 & $520,44 \mathrm{f}-\mathrm{h}$ & $401,86 \mathrm{i}-\mathrm{k}$ & $603,85 \mathrm{~d}-\mathrm{f}$ & $372,00 \mathrm{j}-\mathrm{k}$ & $517,20 \mathrm{f}-\mathrm{h}$ \\
Rejeb 2 & $615,55 \mathrm{~d}-\mathrm{e}$ & $438,13 \mathrm{~h}-\mathrm{k}$ & $686,53 \mathrm{~b}-\mathrm{d}$ & $454,50 \mathrm{~g}-\mathrm{j}$ & $506,53 \mathrm{~g}-\mathrm{h}$ \\
Rejeb 3 & $629,01 \mathrm{~d}-\mathrm{e}$ & $448,53 \mathrm{~h}-\mathrm{k}$ & $515,55 \mathrm{f}-\mathrm{h}$ & $352,50 \mathrm{k}$ & $774,33 \mathrm{ab}$ \\
Rejeb 4 & $643,12 \mathrm{c}-\mathrm{e}$ & $442,27 \mathrm{~h}-\mathrm{k}$ & $737,57 \mathrm{a}-\mathrm{c}$ & $388,50 \mathrm{i}-\mathrm{k}$ & $783,00 \mathrm{a}$ \\
Rejeb 5 & $617,98 \mathrm{~d}-\mathrm{e}$ & $438,73 \mathrm{~h}-\mathrm{k}$ & $731,55 \mathrm{a}-\mathrm{c}$ & $439,20 \mathrm{~h}-\mathrm{k}$ & $661,50 \mathrm{~cd}$ \\
Rejeb 6 & $549,03 \mathrm{e}-\mathrm{g}$ & $478,01 \mathrm{~g}-\mathrm{i}$ & $460,30 \mathrm{~g}-\mathrm{j}$ & $391,50 \mathrm{i}-\mathrm{k}$ & $657,00 \mathrm{~cd}$ \\
Rejeb 7 & $470,55 \mathrm{~g}-\mathrm{j}$ & $437,47 \mathrm{~h}-\mathrm{k}$ & $473,97 \mathrm{~g}-\mathrm{j}$ & $423,00 \mathrm{~h}-\mathrm{k}$ & $609,00 \mathrm{~d}-\mathrm{f}$ \\
\hline
\end{tabular}

Keterangan : Angka-angka yang didampingi huruf sama berarti tidak berbeda nyata pada uji jarak ganda Duncan taraf $5 \%$.

Tabel 4. Indeks mutu 7 kultivar Rejeb pada 5 lokasi pengembangan tembakau di Kabupaten Magetan.

\begin{tabular}{|c|c|c|c|c|c|c|}
\hline \multirow[b]{2}{*}{ Kultivar } & \multicolumn{5}{|c|}{ Indeks mutu pada lokasi } & \multirow[b]{2}{*}{ Rerata } \\
\hline & $\begin{array}{c}\text { Tamanarum } \\
\text { (sawah,2013) }\end{array}$ & $\begin{array}{c}\text { Ngunut } \\
\text { (sawah,2014) }\end{array}$ & $\begin{array}{c}\text { Ngunut } \\
\text { (tegal,2014) }\end{array}$ & $\begin{array}{c}\text { Ngunut } \\
\text { (sawah,2016) }\end{array}$ & $\begin{array}{c}\text { Pendem } \\
\text { (tegal,2016) }\end{array}$ & \\
\hline Rejeb 1 & 69,45 & 59,4 & 50,73 & 62,29 & 65,26 & $61,42 \mathrm{ab}$ \\
\hline Rejeb 2 & 66,67 & 58,48 & 50,5 & 60,41 & 64,69 & $60,15 \mathrm{ab}$ \\
\hline Rejeb 3 & 66,7 & 59,47 & 49,97 & 60,28 & 72,44 & $61,76 \mathrm{ab}$ \\
\hline Rejeb 4 & 62,22 & 60,73 & 48,63 & 66,6 & 80,09 & $63,65 \mathrm{a}$ \\
\hline Rejeb 5 & 61,11 & 62,99 & 47,5 & 55,19 & 74,07 & $60,17 \mathrm{ab}$ \\
\hline Rejeb 6 & 61,11 & 48,89 & 45 & 57,51 & 67,44 & $55,99 \mathrm{~b}$ \\
\hline Rejeb 7 & 63,89 & 57,63 & 44,14 & 59,67 & 64,42 & $57,95 \mathrm{ab}$ \\
\hline Rerata & $64,45 \mathrm{~b}$ & $58,23 \mathrm{c}$ & $48,07 \mathrm{~d}$ & $60,28 \mathrm{bc}$ & $69,77 \mathrm{a}$ & \\
\hline
\end{tabular}


tinggi indeks mutunya. Dalam penelitian ini, indeks mutu tembakau Rejeb hanya dipengaruhi oleh kultivar dan lokasi secara individu. Kultivar Rejeb 4 mrnghasilkan indek mutu tertinggi, sedangkan kultivar Rejeb 6 menghasilkan indeks mutu terendah (Tabel 4). Adapun lokasi yang menghasilkan indeks mutu tertinggi adalah Pendem dan yang terendah adalah Ngunut Tegal.

Indeks tanaman merupakan peubah yang menggambarkan pendapatan yang diperoleh dalam berusahatani tembakau. Semakin tinggi indeks tanaman yang diperoleh semakin tinggi pendapatan yang akan diterima oleh petani. Kultivar Rejeb 4 menghasilkan indeks tanaman tertinggi pada tiga lokasi yakni Ngunut Sawah 2014, Ngunut Tegal dan Pendem (Tabel 5). Kultivar Rejeb 3 dan Rejeb 5 menghasilkan indeks tanaman tertinggi masing-masing di dua lokasi yakni Tamanarum dan Ngunut Sawah 2014 untuk kultivar Rejeb 3 serta Ngunut Sawah 2014 dan Ngunut Tegal untuk kultivar Rejeb 5. Adapun kultivar Rejeb 6 dan Rejeb 7 masing-masing menghasilkan indeks tanaman terendah pada dua lokasi, yakni Ngunut Sawah 2014 dan Ngunut Tegal untuk kultivar Rejeb 6 serta Tamanarum dan Ngunut Tegal untuk kultivar Rejeb 7.

Tabel 5. Indeks tanaman 7 kultivar Rejeb pada 5 lokasi pengembangan tembakau di Kabupaten Magetan.

\begin{tabular}{lccccc}
\hline \multirow{2}{*}{ Kultivar } & \multicolumn{5}{c}{ Indeks tanaman pada lokasi } \\
\cline { 2 - 6 } & $\begin{array}{c}\text { Tamanarum } \\
\text { (sawah,2013) }\end{array}$ & $\begin{array}{c}\text { Ngunut } \\
\text { (sawah,2014) }\end{array}$ & $\begin{array}{c}\text { Ngunut } \\
\text { (tegal,2014) }\end{array}$ & $\begin{array}{c}\text { Ngunut } \\
\text { (sawah, 2016) }\end{array}$ & $\begin{array}{c}\text { Pendem } \\
\text { (tegal,2016) }\end{array}$ \\
\hline Rejeb 1 & $36,09 \mathrm{~d}-\mathrm{g}$ & $23,99 \mathrm{i}-\mathrm{k}$ & $30,64 \mathrm{f}-\mathrm{j}$ & $22,98 \mathrm{jk}$ & $33,83 \mathrm{e}-\mathrm{h}$ \\
Rejeb 2 & $40,01 \mathrm{~d}-\mathrm{f}$ & $25,86 \mathrm{~h}-\mathrm{k}$ & $34,03 \mathrm{e}-\mathrm{h}$ & $27,55 \mathrm{~g}-\mathrm{k}$ & $33,00 \mathrm{e}-\mathrm{i}$ \\
Rejeb 3 & $41,94 \mathrm{c}-\mathrm{e}$ & $26,99 \mathrm{~g}-\mathrm{k}$ & $25,88 \mathrm{~h}-\mathrm{k}$ & $21,02 \mathrm{k}$ & $56,70 \mathrm{ab}$ \\
Rejeb 4 & $40,00 \mathrm{~d}-\mathrm{f}$ & $27,31 \mathrm{~g}-\mathrm{k}$ & $35,63 \mathrm{e}-\mathrm{g}$ & $26,03 \mathrm{~h}-\mathrm{k}$ & $62,76 \mathrm{a}$ \\
Rejeb 5 & $38,64 \mathrm{~d}-\mathrm{f}$ & $27,98 \mathrm{~g}-\mathrm{k}$ & $35,50 \mathrm{e}-\mathrm{g}$ & $24,07 \mathrm{i}-\mathrm{k}$ & $49,25 \mathrm{bc}$ \\
Rejeb 6 & $33,68 \mathrm{e}-\mathrm{h}$ & $23,41 \mathrm{jk}$ & $20,92 \mathrm{k}$ & $22,96 \mathrm{jk}$ & $44,75 \mathrm{~cd}$ \\
Rejeb 7 & $31,19 \mathrm{f}-\mathrm{j}$ & $25,35 \mathrm{~h}-\mathrm{k}$ & $20,70 \mathrm{k}$ & $25,13 \mathrm{~h}-\mathrm{k}$ & $39,79 \mathrm{~d}-\mathrm{f}$ \\
\hline
\end{tabular}

Keterangan : Angka-angka yang didampingi huruf sama berarti tidak berbeda nyata pada uji jarak ganda Duncan taraf $5 \%$.

Tabel 6. Kadar nikotin 7 kultivar Rejeb pada 5 lokasi pengembangan tembakau di Kabupaten Magetan.

\begin{tabular}{|c|c|c|c|c|c|c|}
\hline \multirow[b]{2}{*}{ Kultivar } & \multicolumn{5}{|c|}{ Kadar nikotin $(\%)$} & \multirow[b]{2}{*}{ Rerata } \\
\hline & $\begin{array}{c}\text { Tamanarum } \\
\text { (sawah,2013) }\end{array}$ & $\begin{array}{c}\text { Ngunut } \\
\text { (sawah,2014) }\end{array}$ & $\begin{array}{c}\text { Ngunut } \\
\text { (tegal,2014) }\end{array}$ & $\begin{array}{c}\text { Ngunut } \\
\text { (sawah, 2016) }\end{array}$ & $\begin{array}{c}\text { Pendem } \\
\text { (tegal,2016) }\end{array}$ & \\
\hline Rejeb 1 & 3,06 & 5,35 & 4,63 & 5,64 & 6,56 & $5,05 \mathrm{ab}$ \\
\hline Rejeb 2 & 3,42 & 4,54 & 4,22 & 5,40 & 5,50 & $4,62 \mathrm{~b}$ \\
\hline Rejeb 3 & 2,93 & 4,84 & 5,20 & 5,14 & 5,29 & $4,68 \mathrm{ab}$ \\
\hline Rejeb 4 & 3,00 & 5,28 & 4,89 & 5,17 & 5,36 & $4,74 \mathrm{ab}$ \\
\hline Rejeb 5 & 2,98 & 5,00 & 4,21 & 5,51 & 5,80 & $4,70 \mathrm{ab}$ \\
\hline Rejeb 6 & 3,23 & 5,18 & 5,28 & 5,79 & 6,03 & $5,10 \mathrm{a}$ \\
\hline Rejeb 7 & 2,65 & 5,19 & 4,77 & 5,95 & 5,53 & $4,82 \mathrm{ab}$ \\
\hline Rerata & $3,06 \mathrm{~d}$ & $5,05 \mathrm{bc}$ & $4,74 \mathrm{c}$ & $5,51 \mathrm{ab}$ & $5,73 \mathrm{a}$ & \\
\hline
\end{tabular}


Indeks tanaman tersusun atas komponen hasil rajangan kering dan indeks mutu. Dalam penelitian ini penggunaan analisis linier berganda (Stepwise analysis) diperoleh persamaan regresi linier antara indeks tanaman (ITAN) dengan hasil rajangan kering (Prod) dan indeks mutu (Imut) dengan membentuk persamaan ITAN = 0,060593 Prod + 0,58052 Imut $-34,79965$; $\mathbf{r}=\mathbf{0 , 9 8 9} * *$

Hasil persamaan tersebut memberi arti bahwa kedua komponen penyusun tersebut memberi pengaruh sebesar 98,9\% dalam menentukan besaran nilai indeks tanaman. Penggunaan analisis regresi linier berganda langkah mundur diperoleh rincian besaran pengaruh masing-masing komponen penyusun tersebut adalah $85,6 \%$ untuk hasil rajangan kering dan $13,3 \%$ untuk indeks mutu. Kondisi yang demikian tersebut yang menyebabkan respons indeks tanaman masing-masing kultivar Rejeb terhadap perbedaan kondisi lokasi tumbuahnya menyerupai respons hasil rajangan kering dan jauh berbeda dengan respons indeks mutu terhadap perbedaan kondisi lokasi tumbuhnya (Tabel 2).

Mutu tembakau secara kimiawi tersusun atas kadar gula dan nikotin dalam hasil rajangan kering. Setiap jenis tembakau mempunyai komposisi yang berbeda-beda dalam menentukan mutu tertingginya. Pada tembakau Rejeb belum banyak diketahui komposisi keduanya dalam menentukan mutu tembakau yang dihasilkan. Nikotin merupakan salah satu hasil metabolit sekunder. Pada tanaman tembakau disintesis di akar, lalu ditranslokasi dan diakumulasi ke daun (Shitan et al. 2009). Akumulasi kadar nikotin pada daun akan bertambah seiring bertambahnya umur tanaman.

Kadar nikotin tembakau Rejeb dipengaruhi oleh kultivar tembakau dan lokasi tempat tumbuhnya. Kultivar Rejeb 6 menghasilkan kadar nikotin tertinggi dan yang terendah diperoleh kultivar Rejeb 2. Adapun lokasi Pendem menghasilkan kadar nikotin yang tertinggi dan Ngunut Tegal yang terendah (Tabel 6). Nikotin merupakan salah satu senyawa alkaloid yang dapat memberikan kenikmatan bagi perokok karena rangsangan fisiologisnya terhadap orang yang menghisapnya. Dengan adanya nikotin menyebabkan tanaman tembakau mempunyai cirikhas dan mempunyai nilai komersial. Tanah di Desa Ngunut tergolong tanah lempung berpasir, dimana akar tanaman tembakau akan tumbuh dengan maksimal (Utrera dan Begonia, 1986) sehingga dapat memaksimalkan sintesis nikotin.

Di Desa Pendem yang memiliki tanah bertekstur berat, menyebabkan pertumbuhan akar kurang maksimal dibandingkan pertumbuhan di Desa Ngunut, sehingga sintesis nikotinpun tidak maksimal. Hal ini didukung oleh Buss (1999), dimana pada tanah bertekstur ringan, tanaman tembakau akan menghasilkan kadar nikotin lebih tinggi diandingkan tanah berat.

Respons kadar nikotin terhadap perbedaan kultivar sangat berbeda dengan respons indeks mutu terhadap kultivar (Tabel 4) sehingga seolah-olah kadar nikotin tidak terkait dengan penentuan indeks mutu. Analisis regresi antara indeks mutu (Imut) dengan kadar nikotin (Nik) diperoleh persamaan : 


\section{IMUT $=-0,17185$ Nik $+60,98562 ; r=0,020$}

Persamaan tersebut memberi arti bahwa kadar nikotin hanya memberi pengaruh terhadap indeks mutu sebesar 2,0\%. Hasil tersebut membuktikan bahwa variasi kadar nikotin 2,65-6,03\% pada tembakau Rejeb tidak mempengaruhi indeks mutu yang diperoleh. Kondisi yang demikian menyebabkan respons indeks mutu berbeda dengan respons kadar nikotin terhadap perbedaan kultivar yang digunakan.

\section{Stabilitas Hasil dan Adaptabilitas}

Uji stabilitas hasil dapat dilakukan apabila ada pengaruh interaksi antara kultivar dan lokasi terhadap hasil, baik berupa rajangan kering, indeks mutu, indeks tanaman maupun kadar nikotin. Dalam penelitian ini hanya diperoleh dua peubah hasil (hasil rajangan kering dan indeks tanaman) sehingga uji stabilitas hasil hanya dapat dilakukan terhadap kedua peubah tersebut.

Hasil uji stabilitas pada peubah hasil rajangan kering menunjukkan bahwa kultivar Rejeb 1, Rejeb 2, Rejeb 3, Rejeb 4, dan Rajeb 5 stabil pada lima lokasi pengujian (Tabel 7). Menurut Eberhart dan Russell (1966) suatu kultivar/varietas dinyatakan stabil apabila memiliki nilai koefisien regresi (bi) mendekati 1, nilai simpangan regresi $\left(\mathrm{S}_{\mathrm{di}}^{2}\right)$ mendekati 0 , dan tidak

Tabel 7. Hasil rajangan kering, koefisien regresi (bi) dan simpangan regresi $\left(\mathrm{S}_{d i}^{2}\right) 7$ kultivar Rejeb di Kabupaten Magetan.

\begin{tabular}{lccc}
\hline \multicolumn{1}{c}{ Kultivar } & Hasil rajangan kering (kg/ha) & $\mathrm{bi}$ & $\mathrm{S}_{d i}^{2}$ \\
\hline Rejeb 1 & 483,07 & $0,90^{\text {tn }}$ & $-5466,89^{\text {tn }}$ \\
Rejeb 2 & 540,25 & $0,75^{\text {tn }}$ & $-1355,43^{\text {tn }}$ \\
Rejeb 3 & 543,98 & $1,49^{\text {tn }}$ & $-5106,06^{\text {tn }}$ \\
Rejeb 4 & 598,89 & $2,03^{\text {tn }}$ & $-9007,69^{\text {tn }}$ \\
Rejeb 5 & 577,79 & $1,15^{\text {tn }}$ & $-2613,62^{\text {tn }}$ \\
Rejeb 6 & 507,17 & $0,61^{\text {tn }}$ & $54606,23^{* *}$ \\
Rejeb 7 & 482,8 & $0,60^{\text {tn }}$ & $20959,84^{* *}$ \\
\hline Rataan umum & 554,58 & & \\
\hline
\end{tabular}

Ket : bi : koefisien regresi, $\mathrm{S}_{d i}^{2}$ : simpangan regresi; * : berbeda nyata pada uji $(0,05)$, tn : tidak berbeda nyata pada uji $(0,05)$.

Tabel 8. Indeks tanaman, koefisien regresi (bi) dan simpangan regresi $\left(\mathrm{S}_{d i}^{2}\right) 7$ kultivar Rejeb di Kabupaten Magetan.

\begin{tabular}{lccc}
\hline \multicolumn{1}{c}{ Varietas lokal } & Indeks tanaman & $\mathrm{bi}$ & $\mathrm{S}_{d i}^{2}$ \\
\hline Rejeb 1 & 29,51 & $1,06^{\text {tn }}$ & $16,60^{\text {tn }}$ \\
Rejeb 2 & 32,09 & $0,94^{\text {tn }}$ & $17,42^{\text {tn }}$ \\
Rejeb 3 & 34,5 & $1,25^{\text {tn }}$ & $50,22^{\text {tn }}$ \\
Rejeb 4 & 38,34 & $0,99^{\text {tn }}$ & $14,51^{\text {tn }}$ \\
Rejeb 5 & 35,09 & $0,94^{\text {tn }}$ & $5,19^{*}$ \\
Rejeb 6 & 29,14 & $1,04^{\text {tn }}$ & $31,19^{\text {tn }}$ \\
Rejeb 7 & 28,43 & $1,11^{\text {tn }}$ & $36,47^{\text {tn }}$ \\
\hline Rataan umum & 32,44 & &
\end{tabular}

Ket : bi : koefisien regresi, $\mathrm{S}_{d i}^{2}$ : simpangan regresi; * : berbeda nyata pada uji $\mathrm{t}(0,05)$, tn : tidak berbeda nyata pada uji $\mathrm{t}(0,05)$. 
Tabel 9. Hasil rajangan kering, indeks tanaman, dan stabilitas 7 kultivar Rejeb di Kabupaten Magetan.

\begin{tabular}{lcccc}
\hline \multirow{2}{*}{ Kultivar } & \multicolumn{2}{c}{ Hasil rajangan kering } & \multicolumn{2}{c}{ Indeks tanaman } \\
\cline { 2 - 5 } & Kuantitas $(\mathrm{kg} / \mathrm{ha})$ & Stabilitas & $29,51 \mathrm{c}$ & Stabilitas \\
\hline Rejeb 1 & $483,07 \mathrm{~d}$ & Stabil & $32,09 \mathrm{bc}$ & Stabil \\
Rejeb 2 & $540,25 \mathrm{bc}$ & Stabil & $34,50 \mathrm{~b}$ & Stabil \\
Rejeb 3 & $543,98 \mathrm{bc}$ & Stabil & $38,34 \mathrm{a}$ & Stabil \\
Rejeb 4 & $598,89 \mathrm{a}$ & Stabil & $35,09 \mathrm{ab}$ & Stabil \\
Rejeb 5 & $577,79 \mathrm{ab}$ & Stabil & $29,14 \mathrm{c}$ & Tidak stabil \\
Rejeb 6 & $507,17 \mathrm{~cd}$ & Tidak stabil & $28,43 \mathrm{c}$ & Stabil \\
Rejeb 7 & $482,80 \mathrm{~d}$ & Tidak stabil & Stabil \\
\hline
\end{tabular}

Keterangan : Angka-angka yang didampingi huruf sama dalam satu kolom berarti tidak berbeda nyata pada uji jarak ganda Duncan taraf $5 \%$.

berbeda nyata. Kestabilan berdasarkan analisis Eberhart dan Russell tergolong ke dalam varietas dengan kestabilan dinamis (Becker dan Leon, 1988).

Pengujian terhadap simpangan regresi $\left(\mathrm{S}_{\mathrm{di}}^{2}\right)$ menggunakan uji $\mathrm{F}$ taraf 5\% memperlihatkan bahwa 6 kultivar Rejeb menghasilkan simpangan regresi $\left(\mathrm{S}_{\mathrm{di}}^{2}\right)$ yang tidak berbeda dengan nol (Tabel 8). Hasil uji tersebut memberi arti 6 kultivar Rejeb stabil pada lokasi pengujian (Tabel 8). Menurut Eberhart dan Russell (1966) suatu kultivar/varietas dinyatakan stabil apabila memiliki nilai koefisien regresi (bi) mendekati 1 dan nilai simpangan regresi $\left(\mathrm{S}_{\mathrm{di}}^{2}\right)$ tidak berbeda dengan nol..

Suatu kultivar/varietas yang diuji dikatakan ideal, jika kultivar/varietas tersebut menunjukkan ratarata hasil tinggi dan stabil (Yan dan Kang, 2003). Bila mengacu pada kriteria tersebut, berdasarkan perhitungan indeks tanaman dari 7kultivar yang diuji, Rejeb 4 yang memiliki kriteria sebagai kultivar yang ideal disusul kultivar Rejeb 1, Rejeb 2,Rejeb 3, Rejeb 6,dan Rejeb 7 (Tabel 9). Selain itu ditunjang dengan selera pasar, dimana Rejeb 4 sudah memiliki pasar yang luas di Kabupaten Magetan dengan produk unggulan berupa tembakau rajangan halus untuk komunitas perokok lintingan yang memiliki rasa lebih berat (ampek). Permasalahan saat ini adalah belum adanya pengakuan dari pasar nasional terkait keberadaan tembakau Magetan tersebut.

\section{KESIMPULAN}

Kultivar Rejeb 4 memberikan hasil rajangan kering tertinggi dan stabil yaitu $598,89 \mathrm{~kg} / \mathrm{ha}$, lebih tinggi dibandingkan dengan semua kultivar yang diuji. Hal ini selaras dengan nilai indek mutu dan indek tanaman, dimana varietas Rejeb 4 memberikan hasil tertinggi di lima lokasi pengujian (63,65 dan 38,34). Selanjutnya disusul oleh kultivar Rejeb 3, Rejeb 2,dan Rejeb 1 yang memiliki nilai stabilitas dan adaptabilitas dinamis.

\section{UCAPAN TERIMA KASIH}

Ucapan terima kasih kami sampaikan kepada Ir. Fatkhur Rochman dan Ir. Sri Yulaikah yang telah membimbing selama proses penelitian dan penyusunan karya tulis ini.Kepada Dinas Tanaman Pangan, Hortikultura, Perkebunan, dan Ketahanan Pangan Kabupaten Magetan yang memfasilitasi terselenggaranya penelitian tembakau Magetan. 
Penelitian ini didanai dari kerjasama penelitian tembakau Dinas Perkebunan Provinsi Jawa Timur.

\section{DAFTAR PUSTAKA}

Anonim. 2013.Laporan luas areal dan produksi/ produktivitas perkebunan rakyat. Dinas Perkebunan Provinsi Jawa Timur. Surabaya.

Anonim. 2015.Kebutuhan tembakau nasional tahun 2015. Laporan tahunan Kementrian Perindustrian. Jakarta.

Boegi. 2009. Cigarette flavour basic knowledge. Training of Tobacco Blending. Balittas Malang

Briones, AM and S.K.Obien. 1986. Acrop value index for tobacco.J. Tob. Sci. and Tech. 1:1-14.

Djumali dan E. Nurnasari. 2012. Tanggapan fisiologi tanaman tembakau temanggung terhadap dosis pupuknitrogen serta kaitannya dengan hasil dan mutu rajangan. Buletin Tanaman Tembakau, Serat \& Minyak Industri. 4(1) : 10-20.

Eberhart S.Aand W.A. Russel. 1966. Stability parameters for comparing varieties. Crop Sci. 6:36-40.

Gardner, F.P, R.B. Perace, dan R.L. Mitchell.1991. Fisiologi Tanaman Budidaya. Penerjemah: Susilo, H. Jakarta: UI Press.

Gomez, K.A.danA.A.Gomez.1995.Prosedur Statistik untuk Penelitian Pertanian. Edisi kedua. (Diterjemahkan oleh Endang Sjamsuddin \& Yustika S. Baharsjah). Universitas Indonesia Press. Jakarta. 220 hal.

Jaleel, CA, Manivannan, P, Wahid, A, Farooq, M, AlJuburi, HJ, Somasundaram, $R$ and
Panneerselvam, R. 2009. Drought Stress in Plants: A review on morphological characteristics and pigments composition. International journal of agriculture \& biology. 11 (1) : 100-105.

Satoto, Y. Widyastuti, I.A. Rumanti, dan Sudibyo, T.W.U. 2010.Stabilitas Hasil Padi Hibrida Varietas Hipa 7 dan Hipa 8 dan Ketahanannya terhadap Hawar Daun Bakteri dan Tungro. Penelitian Pertanian Tanaman Pangan. 29(3):129-135.

Suwarso, Rochman, F, Rachman,A,dan Herwati, A. 1996. Varietas unggul tembakau hasil penelitian BALITTAS. (www.pustaka. litbang. deptan.go.id).

Suyanto, A dan S, Tirtosastro. 2006, Permasalahan tembakau rakyat dan dampaknya terhadap industri rokok. Prosiding Diskusi Panel Revitalisasi Sistem Agribisnis Tembakau Bahan Baku Rokok. Puslitbang Perkebunan. Bogor. Hal. 1-8.

Tso, TC. 1999. Seed to Smoke., In tobacco : Production, chemistry, and technology. D.L. David and M.T. Nielsen (Eds.), Blackwell Science. Oxford. 1-31p. 